\title{
MAINSTREAMING DISTANCE LEARNING INTO THE COMMUNITY COLLEGE
}

\author{
Dr. Linda M. Thor \\ President \\ Rio Salado College \\ 2323 West 14th Street, Tempe, AZ 85281-6950 \\ Phone (480) 517-8140; Fax: (480) 517-8149 \\ linda.thor@riomail.maricopa.edu \\ Carol Scarafiotti \\ Dean of Instruction \\ Rio Salado College \\ 2323 West 14th Street, Tempe, AZ 85281-6950 \\ Phone (480) 517-8135; Fax: (480) 517-8149 \\ carol.scarafiotti@riomail.maricopa.edu
}

\begin{abstract}
Rio Salado, one of the Maricopa Community Colleges in the Phoenix metropolitan area, has not only carved a market niche as a leading distance learning provider for working adults, but has experienced double-digit growth increases as high as 40 percent annually in its online enrollments. With unduplicated headcount exceeding 21,000 distance learning students last year, the majority of them enrolled in webbased courses, this college without a campus has been recognized as a national model for online teaching and learning. This article details how Rio Salado has mainstreamed distance learning throughout the entire college.
\end{abstract}

\section{KEY WORDS}

Total Quality Management, Learning Organization, Systems Approach, Branding, Hedgehog Concept

\section{INTRODUCTION}

Rio Salado is proof that new models of higher education can successfully meet the needs of adult students who are not adequately served by traditional learning formats. Whereas other colleges, universities, and for-profit learning institutions have in recent years shifted their focus to the internet as a delivery mode, with varying degrees of success, the major part of the Rio Salado competitive edge stems from the fact that it was founded 25 years ago as an alternative to traditional education. In its early years, Rio Salado saw the potential for and then adopted distance delivery as a means of reaching its target markets. Thus, today e-learning is integral to the entire college and closely tied to its overall mission and growth, rather than existing as a separate division or function.

While Rio Salado's distance learning success can be traced to multiple factors, four strategies have been implemented since 1990 that enabled it to break from the competition by mainstreaming distance delivery throughout every aspect of the college. 
Under Strategy One, which originated in the early 1990s, the college adapted the principles of Total Quality Management (TQM) and simultaneously fine-tuned its original mission of anytime, anyplace education, formalizing it through written culture statements known to all who work for the college. This contributed to the college's preparation for entry into the e-learning market.

During Strategy Two, which occurred in the mid 1990s, the college's growth began to increase significantly, as it evolved from using the principles of TQM for its primary management model to the Learning Organization, with a focus on organizational learning. The systems approach in particular allowed Rio Salado to more readily respond to, as well as anticipate, internal and external change, particularly as it pertains to distance learning.

With Strategy Three, the college launched its first e-learning courses in 1996 and proceeded to brand them through such innovations as twenty-six term starts each year.

Through Strategy Four, the college has concentrated on maturing its e-learning offerings by implementing and growing model online programs that generate surges in headcount and Full Time Equivalent Enrollment (FTEE).

\section{HISTORICAL PERSPECTIVE}

To more fully understand how the college successfully developed and mainstreamed its distance delivery model, it is necessary to provide a brief retrospective regarding the college's origins and growth patterns. When it was established in 1978, Rio Salado was charged with developing nontraditional formats to reach an emerging market: unserved and underserved adults, with careers and families, who require flexible and convenient learning formats in order to complete their degrees. What was most unusual at the time was Rio Salado's status as "the college without walls" and its reliance upon adjunct faculty to deliver its courses. Rio Salado has never built a traditional campus. Rather, from its Tempe, Arizona administrative headquarters, Rio Salado uses technology and forges partnerships to deliver educational opportunities to diverse populations throughout Maricopa County and around the world.

From the start, Rio Salado as a whole was a popular alternative to its more traditional Maricopa sister colleges, enrolling some 7,000 students in its first semester, primarily onsite at libraries, public facilities, and schools.

One aspect of Rio Salado's earliest days was its course offerings in distance learning. Some of Rio's earliest pioneering efforts in distance learning courses of the late 1970s and early 1980s consisted of correspondence courses, radio courses, and experimental programming on local TV stations, whereby general-interest programming on computers, healthcare issues, and job skills were aired at 6 a.m. weekdays. These programs served limited markets and were inconvenient for multiple reasons. First, they were not truly interactive. Second, while they could probably be taken "anyplace," such as in the convenience of a home or office setting, the media-dependent courses lacked the true "anytime" characteristics necessary for asynchronous learning. Also, although there was some focus on offering individual courses such as English or the humanities, there was no effort to develop model programs that would generate income and enrollments. Furthermore, distance learning was treated more as a department rather than a focal point of the college. As a result of all these factors, these early and unsophisticated distance learning courses experienced limited enrollments, a pattern that continued for more than 15 years. 
However, as the marketplace changed, Rio Salado faced fierce competition both internally within its district and externally with other higher education institutions. Distance learning innovations that had been unique to the college were duplicated by others. With technological advances, Rio Salado found its competition for distance learning students had increasingly become global. By 1990, Rio Salado realized that it had entered a new era, one in which the college would have to re-examine its purposes, processes, and culture in order to elevate the college to the next level of service. In fact, its administrators and faculty realized that its very survival was at stake. Rio Salado was going to have to implement major changes in order to survive and thrive.

\section{FOUR STRATEGIES LEADING TO DISTANCE LEARNING BREAKOUT SUCCESS}

\section{A. Strategy One: An Emphasis on Total Quality Management to Change the Organization's Culture}

In late 1990, the college began an organizational shift that would totally redirect the college's energies and, ultimately, its mission, while paving the way for it to become a national model for asynchronous learning. Recognizing the impending need for change, Rio Salado became one of the first higher education institutions to adapt the principles of Total Quality Management (TQM), a popular management model for businesses at the time. Over the course of several years, TQM principles, with their emphases on quality, customer service, and process improvement, became part of Rio's institutional culture.

After just two years of TQM applications, Rio Salado was honored as a recipient of the 1993 Arizona Governor's Award for Quality, which is called the Pioneer Award. Rio was cited specifically for excellence in bringing quality improvement and quality management to the college through the TQM philosophy. The award is patterned after the Malcolm Baldrige National Quality Award. Rio Salado was the only institution of higher education to receive this honor.

However, the Rio Salado TQM transformation turned out to be an interim step on the road to becoming an educational change agent. This model initially served the college well, with its "plan, do, check, act" philosophy (Figure 1) and its emphasis on continuous-improvement teams.

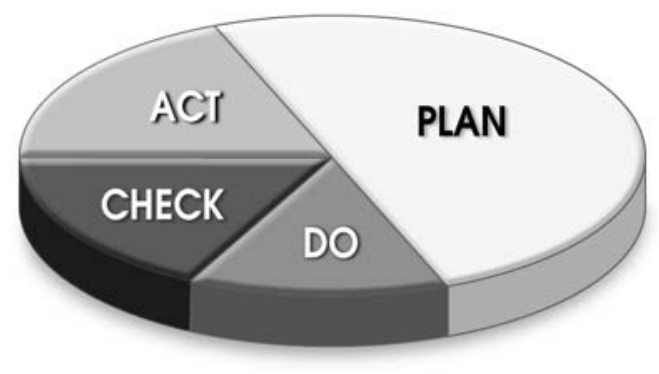

Figure 1. TQM: Plan, Do, Check, Act.

But after several years, the college found that it needed to move on to another, more flexible management model, one that would allow it to adapt with speed to both external changes in higher education and 
internal changes in the system.

During this same period, the college assessed its original mission to serve unserved and underserved student populations. While the college remained true to its original purpose, it underwent a deliberate strategic transformation with the goal of becoming the college of choice for working adults. The redefined mission statement, which has been occasionally modified but is still operational in 2003, has a threefold focus: customized, unique programs and partnerships; "accelerated formats;" and distance learning, particularly through internet courses.

\section{B. Strategy Two: Adaptation of Peter Senge's Five Disciplines of a Learning Organization}

In 1994, faced with the need to adapt to change while growing its distance learning on a larger scale, the college leadership asked two questions: (1) What step would help the college maintain a competitive edge? and (2) What management model would enable the college to take that step? They found answers in Peter Senge's concept of the learning organization from his book, The Fifth Discipline. "A Learning Organization is a place where people continually expand their capacity to create its future, where adaptive learning is joined by generative learning" [1].

Senge's "Five Disciplines of a Learning Organization" also seemed to be a good fit with the college's needs and with its TQM foundation. Moreover, the concept seemed to point the way to take the organization to the next level. The Learning Organization philosophy consists of five components:

- Personal mastery. Learning to expand the individual's personal capacity to create desired results, and creating a culture that encourages all members to develop so that they can achieve their goals and purposes

- Mental models. Continually reflecting on clarifying and improving the individual's internal pictures of the world and noticing how individuals shape actions and decisions

- Shared visions. Building group commitment by developing shared images of the future the college seeks to create and the principles and guiding practices by which it expects to get there

- Team learning. Transforming conversational and collective thinking skills so that groups can reliably develop intelligence and ability greater than the sum of their individual members' talents

- Systems thinking. Learning a new way of thinking about, describing, and understanding the forces and interrelationships that shape the behavior of systems, to see how to change systems effectively, and to act in tune with the larger natural and economic processes

The systems thinking or systems approach was the component that ultimately led to some of the greatest changes and innovations in Rio Salado's approach to distance learning and the college as a whole. In systems thinking, the performance of a system depends on the performance of its parts and on how the parts interact with each other to affect the performance of the whole. At Rio Salado, systems thinking 
came to mean that employees must think beyond their segregated functions or departments; they must recognize the implications of their work for the larger system. No longer can employees think exclusively within their segregated functions. Rather, they must recognize the implications of their work for the larger system. This is especially important as teams work on innovations.

During the time that Learning Organization principles were being adapted by Rio Salado, the internet was quickly emerging as a new medium with vast potential for higher education. Here at last was the technological tool that was capable of elevating Rio's entire distance learning outreach to its full potential. Rio Salado realized it was uniquely positioned to capitalize on this latest modality-e-learning - for delivering courses.

With the transition of the college to the Learning Organization principles, Rio Salado also placed an emphasis on career-path general education, academic, and applied courses for credit. These were to be the foundation courses for the college's new entries into online learning.

Distance learning on a significant scale requires a huge commitment of resources, planning, and management. From its TQM and Learning Organization management models, the college realized that providing quality distance learning entails meeting the needs of not one, but two kinds of customers: the distance learner, and everyone involved in distance learning delivery. Therefore, rather than maintaining a separate distance learning division, Rio Salado made the conscious decision to integrate it into every aspect of the college.

Rio Salado recognized early on that a commitment to e-learning would require substantial changes to how it provided support services. To ensure that the college's Number One customer, the student, had the best service possible, Rio Salado decided to offer all major college services over the internet. That included registration, textbook orders, academic advising and counseling, tutoring, and applications for financial aid. Other services were added later.

The Senge discipline of systems thinking became the model for this integration, known as the Systems Approach, as shown in Figure 2. Rio Salado identified eight specific functions involved in distance learning delivery and set up a systems approach to coordinate them. They are: course production and support; student enrollment services; adjunct faculty services; marketing; online library/media support; faculty and staff development; instructional and technical support; and institutional research. 


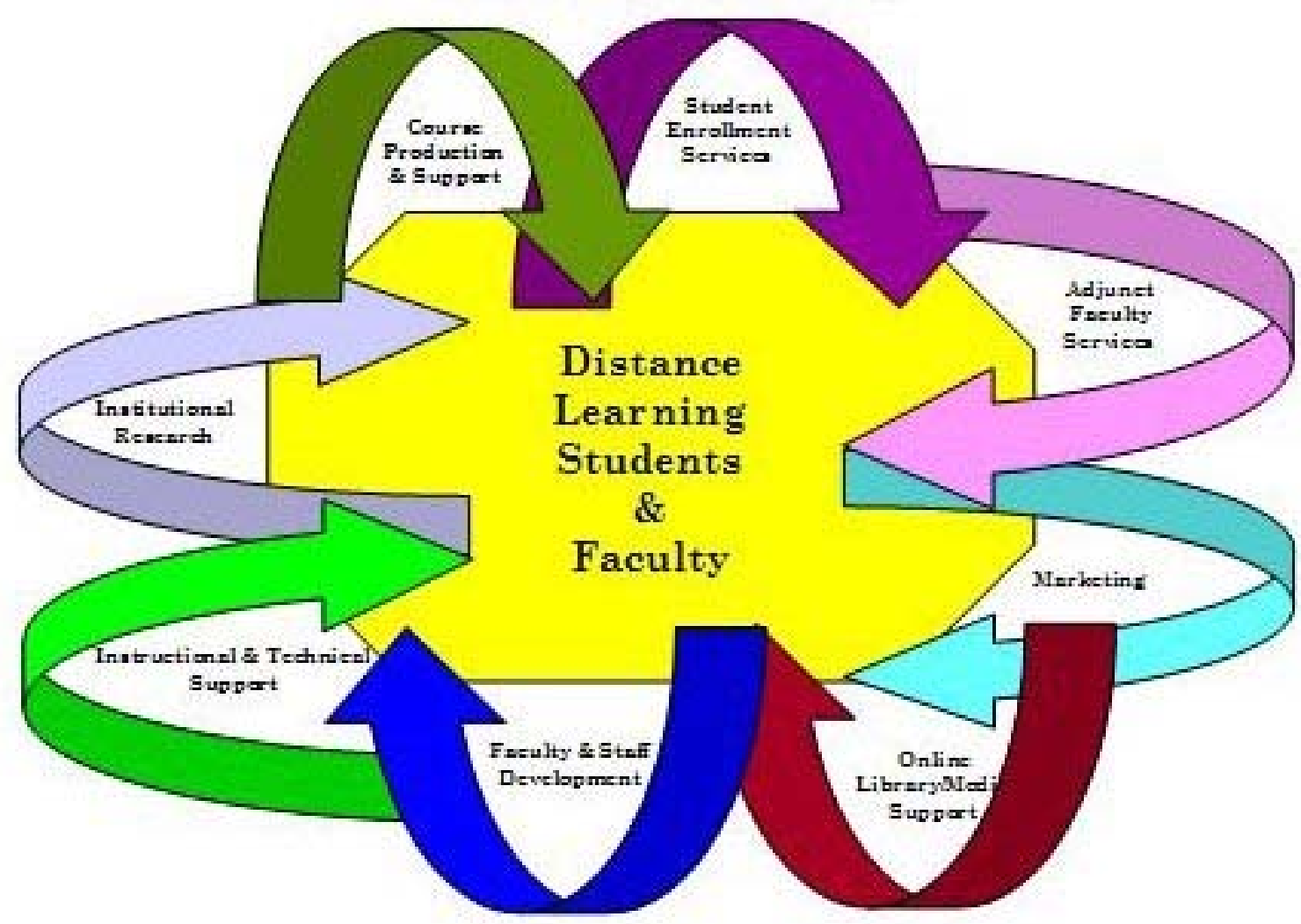

Figure 2. The Rio Salado Systems Approach.

This integrated approach keeps everyone working together for the best interests of the student. No longer would distance learning be a separate function of the college; from this point on, it would impact every area.

\section{Strategy Three: Introduction of E-Learning With a Focus on Branding}

The culmination of several years of adapting Learning Organization principles and the systems approach occurred in the fall of 1996, when the first e-learning courses were introduced. Rio Salado became the first college in Arizona, and one of the first in the nation, to not only place college courses online, but to offer all necessary student support over the internet as well.

Rio Salado had learned earlier in its history that innovations can often be duplicated by competitors, thus reducing their impact at the point of origin. To ensure that Rio Salado would remain an e-learning pioneer, the college determined to brand its offerings. For seven years, the college has conducted formal and informal student focus groups, surveys, and general research with the ultimate goal of incorporating this feedback to attain "customer astonishment" for its students. Rio Salado continually strives to implement e-learning differences and competitive advantages designed to keep the college in the forefront of the asynchronous movement.

Chief among these branding factors is a consistent emphasis on convenience, flexibility, and affordability. Many other specific benefits and innovations flow from these three trademarks of distance learning at Rio Salado. 
For example, one of the most popular branding characteristics has been "26 starts." With the launch of its first online courses, Rio Salado in effect eliminated the traditional semester by conducting start dates every two weeks for the majority of its web-based courses. The longest a student has to wait to begin most e-learning courses is just two weeks. The college's own research determined this is an optimum number for most students. This innovation would have been impossible without the structure provided by the systems approach.

Another branding difference can be found in the online support services. In addition to the services mentioned earlier, students in the year 2003 can download any of 1,800 virtual books, and access a Technical Helpdesk seven days a week. A separate Instructional Helpdesk answers common student questions and walks them through the basics, thus freeing instructor time that can be more appropriately devoted to teaching.

To provide equal footing for newcomers to online learning, a Successful Start program has been formulated that guides students from the process of online registration through the first two weeks of class. In fact, the entire college schedule has been available online, as well as in a print format, since 1996. However, students can take advantage of previewing any individual course online through the posting of the syllabus.

Some students appreciate the fact that with instructor approval they can accelerate their 14-week courses and finish ahead of schedule. Rio Salado's adjunct faculty members are trained and encouraged to build one-on-one relationships with their students in a way that would be impossible in the traditional classroom. Students appreciate the individual attention they receive.

\section{Strategy Four: Concentration on Sustaining Growth Through Model Online Programs and Partnerships}

The premise of "From Good to Great" [2] identifies six concepts that distinguish certain organizations able to make the leap to prosperity and market success while others with similar potential fail to complete the transition. One of these, the hedgehog concept, outlines the formula of "simplicity within the three circles:" identifying what the organization can be the best in the world at; what drives its economic engine; and what it is deeply passionate about. Time and again, established companies make exponential leaps in their growth when they clarify their hedgehog concept.

This hedgehog concept aptly describes Rio Salado's pattern for dynamic growth resulting from the clarification of its mission and adherence to Learning Organization principles. The college began to experience significant headcount and FTEE surges in growth in 1994, four years into clarifying its mission statements and implementing TQM tools into its culture.

A substantial portion of this growth resulted from the college's new mission focus. By the mid-1990s, dozens of customized onsite educational service partnerships had been forged with corporations and government agencies. In addition, by that time the college had also devoted more than 15 years to testing and fine-tuning various distance delivery formats, finally settling on just three modalities: mixed media (audio and videocassettes); print-based materials; and ultimately, in 1996, the introduction of the internet. In fact, it was the web-based courses that led to exponential growth in the college's distance learning program. 
Although the total number of distance learning courses has remained relatively stable for three years (approximately 350 total distance, nearly 250 internet in 2003), the number of students drawn to this form of alternative college learning has surged.

In the fall of 1996, the inaugural semester for internet courses, the college's high point for duplicated distance learning enrollments for all delivery modalities stood at 2,975. This was after nearly 17 years of distance delivery. In contrast, one year later the high point climbed to 3,721, and by fall 1998, it had escalated to 6,043 - more than a 100 percent increase in just two years. By the 2002-2003 academic year, approximately 21,000 distance learning students accounted for some 48,000 duplicated enrollments. The vast majority (more than three-fourths) of these enrollments occurred in web-based courses.

Likewise, as Figure 3 illustrates, the college's FTEE for distance learning has escalated from approximately 500 FTEE, or 10 percent of the total college FTEE in 1995, to 4,000 FTEE, or approximately 48 percent of the college's total FTEE by the end of 2003.

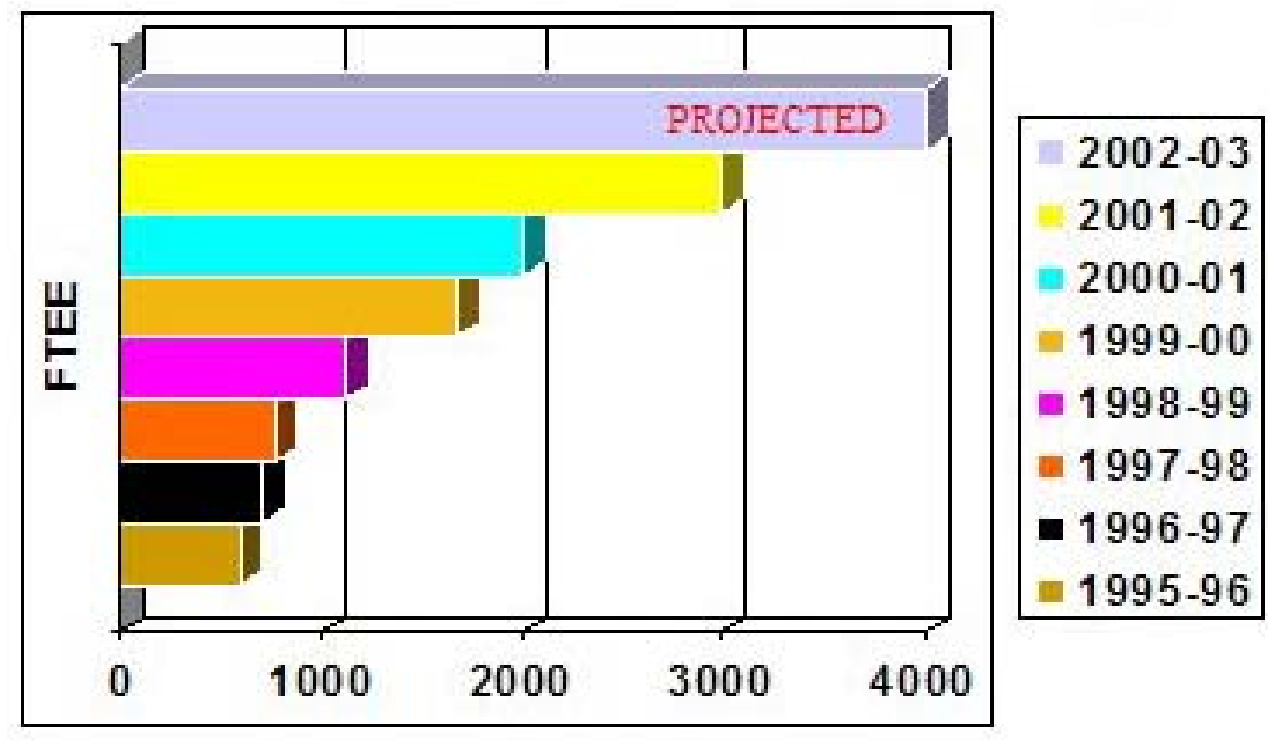

Figure 3. Rio Salado's Distance Learning FTEE Growth.

Clearly the demographics of Rio Salado's adult student population and their values matched the profile of the average internet user: young (average age 32), female, with an emphasis on mothers with young children who are re-entry students, as well as those at a midpoint in their lives who wished to recareer.

With the resulting surge in headcount due to the popularity of the internet format, Rio Salado determined to move from individual course offerings to entire occupational programs that catered to the needs of adults who wished to recareer but could not find the time to attend traditional in-person classes.

Furthermore, the college broke new ground by developing model programs that were previously considered off limits for nontraditional delivery formats. These programs offer all coursework online but provide the hands-on experience through onsite practicums and internships. For example, the college has found success with online clinical dental assisting, a program launched in partnership with the Arizona Dental Association. Each student receives a unique distance lab kit with the tools of the trade that enables them to practice their lessons in the convenience of their homes, prior to their practicums. More than 300 
students have enrolled in the program's first two years.

Another model program, under the banner of Teacher Education, has more than 2,000 unduplicated enrollments after two and a half years. The program was made possible when new stipulations allowed community colleges to offer courses leading to teacher certification, specifically for those who had already earned their undergraduate degrees in other subjects. This approval paved the way for Rio Salado’s flagship education program, Online Post Baccalaureate Teacher Preparation.

Rio has also capitalized on the continuing educational needs of military members who are deployed, seeking promotions, or wishing to transition to civilian life. The college has experienced enrollment of $3,500+$ service members to date through its status as a designated partner with the U.S. Army for the military's eArmyU program. The college currently is the third largest partner-provider for eArmyU.

The most recent applied program launch (fall 2003) is Online Nursing. Rio Salado has received approval from the Arizona State Board of Nursing to offer this 25-credit-hour program designed specifically for licensed practical nurses who want to become registered nurses. Through a distinctive combination of online courses and onsite clinical laboratory work, students can complete the program in two semesters. Rio's nursing program is part of the Maricopa Community College Nursing Program (MCCNP) and leads to the Associate of Applied Science degree in nursing. The program is expected to significantly expand by fall 2004.

The latest step in advancing these model programs has been the formation of partnerships to ensure that credits earned through programs such as Teacher Education can smoothly articulate for undergraduate and even master's degree programs. Thus, a partnership for a baccalaureate degree has been developed with Charter Oak State College in Connecticut, and another partnership for a master's degree in education has been developed with Walden University, both for the benefit of Rio's teacher education students.

\section{CONCLUSIONS}

The success of Rio Salado in mainstreaming its distance learning and launching e-learning can be attributed to four strategies:

- Strategy One: An emphasis on Total Quality Management to Change the Organization's Culture

- Strategy Two: Adaptation of Peter Senge's Five Disciplines of a Learning Organization

- Strategy Three: Introduction of E-Learning with a Focus on Branding

- Strategy Four: Concentration on sustaining growth through model online programs and partnerships

In the fall of 2003, Rio Salado offered nearly 250 e-learning courses and a total of 350 distance learning courses (other formats are mixed media and the familiar print-based materials). The college is continuing its track record of double-digit growth, and expects to easily surpass the 2002-2003 academic year headcount of 21,000+ distance learning students* who accounted for some 48,000 duplicated enrollments. More than 75 percent of these students choose the e-learning option.

The college continues to focus on serving the needs of an unserved and underserved target market: working adults with families, who demand convenience, flexibility, and affordability from their learning 
institutions.

The college also continues to rely primarily on nearly 800 adjunct faculty members who are continually trained in online teaching and learning methodologies through semiannual training sessions on topics such as assessment and learning, and through in-person discipline dialogues.

A new course delivery and management system is planned for introduction in the near future to provide state-of-the-art interaction and service for both students and instructors.

It is interesting to note that throughout its history, Rio Salado has remained the most cost-effective of all 10 Maricopa Community Colleges, due to its lack of a physical campus, its reliance on technology as a tool to deliver education, and its effective use of adjunct faculty. Rio Salado has proven that distance learning, and in particular, e-learning, are viable options for today's students, and that distance learning can effectively be mainstreamed into the college when the college adapts appropriate advance strategies that include a workable management model as the framework for change.

*Note: The college's total 2002-2003 credit headcount was 38,419, with additional enrollments coming in the form of high school dual enrollment, partnerships with corporations and government agencies for onsite education; and accelerated formats.

\section{REFERENCES}

1. Senge, P. M. The Fifth Discipline. New York: Doubleday/Currency, 6-7, 68-69, 1990.

2. Collins, J. Good to Great. New York: HarperCollins Publishers, Inc., 90-119, 2001.

\section{ABOUT THE AUTHORS}

Linda M. Thor is President of Rio Salado College, Tempe, Arizona. Rio Salado, which serves some 38,000 credit and 16,000 noncredit students annually, is one of the 10 colleges that comprise the Maricopa Community Colleges. Rio Salado is a "college without walls" that specializes in serving working adults through distance learning, customized degrees with corporations and government, and accelerated programs. Prior to joining Rio Salado in 1990, Dr. Thor was President of West Los Angeles College. That appointment in 1986 followed 12 years of service to the Los Angeles Community College District as Senior Director of Occupational and Technical Education, Director of High Technology Programs, and Director of Communications Services. She received the B.A. degree in journalism from Pepperdine University, the M.P.A. degree from California State University, Los Angeles, and the Ed.D. degree from Pepperdine University.

Carol Scarafiotti is the Dean of Instruction at Rio Salado College, a community college nationally recognized as a role model for innovation and excellence in online learning. Having led the effort to create a system's approach to distance learning at Rio Salado College, she has firsthand knowledge of what it takes sustain a distance learning program with over 220 distinctive fully online courses, with registration available every two weeks, and with 22,000 students enrolled annually. In 2002, she and Patricia S. Case, also of Rio Salado, received the Sloan C Award for Excellence in Online Access. She is recognized for her collaborative approaches with faculty in achieving innovative instructional design and support systems and for her expertise in assessment of learning outcomes and development of adjunct faculty support services. She frequently speaks at conferences about issues related to the online learning culture in higher education. 